\title{
Influence of different periods of pre-slaughter fasting on microbiological quality of bullfrog carcasses (Lithobates catesbeianus)
}

\author{
[Influência de diferentes períodos de jejum pré-abate na qualidade microbiológica de carcaças \\ de rã-touro (Lithobates catesbeianus)] \\ P.C. Costa ${ }^{1}$, Y.F. Nascimento ${ }^{2}$, L.R.M. Costa 2 , S.C. Dias ${ }^{2}$, N.K.O. Ventura ${ }^{3}$, \\ R.S. Yamatogi ${ }^{4}$, F.A.A. Costa ${ }^{5}$, M.V.C. Cossi ${ }^{5 *}$ \\ ${ }^{1}$ Aluno de pós-graduação - Universidade Federal de Uberlândia - Faculdade de \\ Medicina Veterinária - Uberlândia, MG \\ ${ }^{2}$ Aluno de pós-graduação - Universidade Estadual Paulista - Faculdade de Medicina \\ Veterinária e Zootecnia - Botucatu, SP \\ ${ }^{3}$ Aluno de pós-graduação - Universidade Federal de Viçosa - Viçosa, MG \\ ${ }^{4}$ Universidade Federal de Viçosa - Viçosa, MG \\ ${ }^{5}$ Universidade Federal de Uberlândia - Faculdade de Medicina Veterinária - Uberlândia, MG
}

\begin{abstract}
The aim of this study was to evaluate the influence of different periods of pre-slaughter fasting (F1: 2 to 24 hours and F2: 48 to 72 hours) on the counts of hygiene indicator microorganisms and the presence of Salmonella spp. in carcasses of bullfrogs. Two different stages of the slaughter process were analyzed: after bleeding (A) and after the final carcasses cleaning (B). Samples from each fasting period were analyzed to count hygiene indicator microorganisms $(\mathrm{n}=30)$ and Salmonella spp. $(\mathrm{n}=140)$. For aerobic mesophilic microorganisms, the variation in fasting periods caused a reduction of $0.69 \log _{10} \mathrm{CFU} / \mathrm{g}(\mathrm{P}<0.05)$ in F2 when compared to $\mathrm{F} 1$ at point $\mathrm{B}$ of the slaughter. Coliforms at $35^{\circ} \mathrm{C}$ and Escherichia coli showed no differences $(\mathrm{P}>0.05)$ between the fasting analyzed periods. Considering the presence of $E$. coli, it was observed that F2 resulted in a reduction of $30 \%(\mathrm{P}<0.05)$ positivity on point B. For Salmonella spp., the results showed that $\mathrm{F} 2$ contributed to an $11.5 \%$ reduction in the presence of this bacteria at point $\mathrm{B}$. $(\mathrm{P}<0.05)$. Therefore, it is concluded that 48 to 72 hours of pre-slaughter fasting resulted in a positive impact on the microbiological quality of bullfrog carcasses.
\end{abstract}

Keywords: food safety, hygiene indicator, Salmonella spp

\section{RESUMO}

O objetivo deste estudo foi avaliar a influência de diferentes períodos de jejum pré-abate (F1: duas a 24 horas e F2: 48 a 72 horas) nas contagens de micro-organismos indicadores de higiene e na presença de Salmonella spp. em carcaças de rãs-touro. Foram analisadas duas etapas do processo de abate: após a sangria (A) e após a toalete final da carcaça $(B)$. As amostras de cada período de jejum foram utilizadas para contagem de indicadores de higiene $(n=30)$ e Salmonella spp. $(n=140)$. Para aeróbios mesófilos, a variação no tempo de jejum causou uma redução de $0,69 \log _{10} U F C / g(P<0,05)$ em F2 quando comparado a $F 1$ na etapa $B$ do abate. Os coliformes a $35^{\circ} \mathrm{C} e$ Escherichia coli não apresentaram diferenças $(P>0,05)$ entre os dois períodos de jejum analisados. Considerando a presença de E. coli, F2 resultou em uma redução de $30 \%(P<0,05)$ de positividade na etapa B. Para Salmonella spp., os resultados mostraram que $F 2$ contribuiu para uma redução de 11,5\% na presença desse micro-organismo na etapa B. Portanto, conclui-se que 48 a 72 horas de jejum pré-abate tiveram um impacto positivo na qualidade microbiológica das carcaças de rã-touro.

Palavras-chave: indicador de higiene, Salmonella spp., segurança de alimentos

Recebido em 7 de maio de 2020

Aceito em 14 de dezembro de 2020

*Autor para correspondência (corresponding author)

E-mail: marcuscossi@yahoo.com.br 


\section{INTRODUCTION}

Bullfrog (Lithobates catesbeianus Shaw, 1802) production in Brazil began in the early 1930s and since then much has been invested in the development of techniques and technologies that increase the efficiency of production systems (Cribb et al., 2013; Pahor-Filho et al., 2019). Despite studies carried out worldwide regarding the production of this species, many gaps are still causing problems in the production chain and need to be investigated (Li et al., 2019). Some of these gaps are directly related to bullfrog meat, the final objective of the production chain. Therefore, studies that relate the impact of different species, production systems, and pre-slaughter management with the microbiological quality of the retail product are important for food safety and consumer health (Cantlay et al., 2017).

One of the steps that can be evaluated in this regard is the influence of pre-slaughter fasting time on the number of hygiene indicator microorganisms in the carcass or the presence of pathogenic microorganisms such as those belonging to the genus Salmonella spp. and Escherichia coli (Pointon et al., 2012). Both bacterial genus are recognized worldwide as important causes of foodborne illnesses with symptoms that can vary from fever, abdominal cramps, blood in the stool and, in some cases, may become fatal (Doenças..., 2019). In Brazil, legal standards are established for the main species of production, however, there is no definition of the appropriate pre-slaughter fasting period for amphibians (Brasil, 2017). The concern about the safety of the product becomes even more relevant when we observe that there is a worldwide growth in the consumption of frog meat, with it even being recommended as an option in some functional diets (Oliveira et al., 2017; Lin et al., 2020).

Considering this increase in consumption and the need to obtain safe food products, the objective of the present study was to evaluate the influence of different periods of pre-slaughter fasting on the counts of hygiene indicator microorganisms and the presence of Salmonella spp. in carcasses of bullfrogs analyzed at different stages of the slaughter process.

\section{MATERIAL AND METHODS}

The study was carried out in Uberlândia, Minas Gerais-Brazil, in a closed breeding system, in which all stages of the production chain are carried out within the farm itself, from tadpole production to slaughter. In the bullfrog farming, a wet system was used, with an average density of 50 animals per $\mathrm{m}^{2}$. The frogs were slaughtered between the ages of four and six months, and with an average weight of 462.6 grams $( \pm 87.3 \mathrm{~g})$. The slaughter was carried out in a slaughterhouse, once a day during the morning shift, located on the farm itself, following all the procedures recommended for the species (Cribb et al., 2013). This study was carried out between October and March (Spring to Autumn) with an average temperature of $24.83 \pm 1.35{ }^{\circ} \mathrm{C}$.

On a weekly basis, after morning feeding, 20 animals were selected and equally distributed in two fasting period stalls, F1 (until 24 hours, the usual fasting period) and F2 (over 24 hours). In order to increase the scope of the study, since there are no studies comparing different fasting periods for bullfrogs with the microbiological quality of the carcass, a subdivision was proposed. At F1 stall, 05 animals were slaughtered after a period of 02 hours of fasting and the 05 remaining after a period of 24 hours. Analogously, at F2 stall, 05 animals were slaughtered after a period of 48 hours of fasting and the 05 remaining after a period of 72 hours. Both fasting period stalls had 10 animals per square meters, were previously sanitized and kept with constant water renewal. The above-mentioned protocol was approved by an ethics committee (CEUA 027/2017).

During slaughter, samples were then obtained by superficial rinsing of the carcass, with each carcass sampled at two different points: after bleeding (Point A) and after the final carcasses cleaning with chlorinated water shower $(5 \mathrm{ppm})$ (Point B). In total, 30 carcasses from each fasting period were analyzed to count the hygiene indicator microorganisms at both slaughter steps (A and B). For the research on Salmonella spp., considering its direct importance for public health, samples were collected from 140 bullfrog carcasses (70 animals for each evaluated fasting period analyzed at both slaughter points A and B).

Before rinsing, each carcass was weighed and then allocated into a sterile bag containing $100 \mathrm{~mL}$ 
of sterile $0.85 \% \mathrm{NaCl}$ solution, and then manually rinsed for 30 seconds, while ensuring that all surface areas were covered by the rinsing solution (Cason et al., 2006). The rinse product was kept in a Styrofoam box with ice until it arrived at the Laboratory of Inspection and Technology of Products of Animal Origin at the Faculty of Veterinary Medicine of the Federal University of Uberlandia (FAMEV-UFU).

The post-rinse product was subjected to decimal serial dilutions in $9 \mathrm{~mL}$ of peptone saline $(0.1 \%)$. For aerobic mesophilic (AM) counting, the samples were homogenized with PCA (Plate Count Agar) in sterile petri dishes and incubated at $37^{\circ} \mathrm{C}$ for 48 hours. The counting of Total Coliforms (TCC) at $35^{\circ} \mathrm{C}$ and Escherichia coli (EC) was carried out using Petrifilm ${ }^{\mathrm{TM}}$ EC (3M Company, St. Paul, MN, USA) following the manufacturer's recommendations. The AM, TCC and EC counts were adjusted taking into account the weight (grams) of the carcasses and the results were expressed in $\log _{10} \mathrm{CFU} / \mathrm{g}$. For this adjustment, the following calculation method was used:

$m L=\mathrm{CFU} / \mathrm{mL}$

$$
C F U / g=\frac{m L}{w / v}
$$

$w=$ carcass weight at rated point

$v=100 \mathrm{~mL}$ volume constant in the rinse bag

Salmonella spp. were also investigated in the rinse product, using $25 \mathrm{~mL}$ of the rinse in $225 \mathrm{~mL}$ of Buffered Peptone Water (1\%), then following the steps of the International Organization for Standardization Method 6579 (International..., 2002). Samples with typical characteristics in LIA (Lysine Iron Agar - TMMedia ${ }^{\circledR}$ ) and / or TSI (Triple Sugar Iron Agar - TMMedia ${ }^{\circledR}$ ) were confirmed by Polymerase Chain Reaction (PCR), using the ompC gene as targets (ompC-F 5"ATCGCTGACTTATGCAATCG-3" and ompCR 5"-CGGGTTGCGTTATAGGTCTG-3") (Almeida et al., 2014; Alvarez et al., 2004). After confirmation, positive isolates were subjected to serotyping at the Oswaldo Cruz Foundation (Fiocruz, Rio de Janeiro, RJ, Brazil).

In order to compare the microbiological counts of AM, TCC and EC obtained in steps A and B, the Mann-Whitney test was used $(\mathrm{P}<0.05)$. To compare the contamination averages obtained in each analyzed fast, the Wilcoxon matched-pairs signed rank test $(\mathrm{P}<0.05)$ was used. Finally, comparisons of frequencies of Salmonella and $E$. coli in each analyzed fasting period were made using Fisher's exact test $(\mathrm{P}<0.05)$. All statistical analyses were performed using the GraphPad Instat software.

\section{RESULTS}

There was no impact of the fasting periods on the AM count in step A of slaughter $(\mathrm{P}>0.05)$. In step $\mathrm{B}$, the fasting period of 48 to 72 hours resulted in a reduction of $0.69 \log 10 \mathrm{CFU} / \mathrm{g}$ in carcass contamination compared to those subjected to a shorter fasting period $(\mathrm{P}<0.05)$. It is also noted that with a short fasting period (2 to 24 hours), carcasses presented greater contamination at point $\mathrm{B}$ compared to point $\mathrm{A}(\mathrm{P}<0.05)$, which is not observed in a long fasting period (48 to 72 hours) $(\mathrm{P}>0.05)$ (Table 1).

In the evaluation of coliform at $35^{\circ} \mathrm{C}$, no differences were identified between fasting periods and between slaughter points $\mathrm{A}$ and $\mathrm{B}(\mathrm{P}>$ 0.05). Although the presence of this group of microorganisms was identified in 95\% (114/120) of the analyzed samples, it is noted that the mean counts were low, being less than $1 \log _{10} \mathrm{CFU} / \mathrm{g}$ in $75 \%(90 / 120)$ of the samples (Table 2).

As observed for coliforms at $35^{\circ} \mathrm{C}$, the comparison of the average Escherichia coli counts also did not indicate any difference between fasting periods and between slaughter steps A and B (P> 0.05) (Table 3). However, considering that $61 \%(73 / 120)$ of the total samples evaluated were negative for this bacterium, a second analysis was also carried out to assess the impact of fasting period on the presence of this microorganism in both slaughter steps A and B (Table 4).

In the evaluation of the impact of fasting on the presence and absence of $E$ coli, it was observed that the long period of fasting resulted in a reduction of $50 \%$ to $20 \%$ positivity in step B of slaughter, right after the final carcasses cleaning with running water $(\mathrm{P}<0.05)$. In step $\mathrm{A}$, although there was a reduction from $70 \%$ to $43.3 \%$, it was not possible to demonstrate a statistical difference, however, there is a reduction trend that a larger number of samples could be sufficient to identify. 
Table 1. Mean counts (log CFU/ grams) of aerobic mesophilic in bullfrog carcasses subjected to different fasting period, collected at two steps of the slaughtering process, in a slaughterhouse located in the state of Minas Gerais-Brazil

\begin{tabular}{|c|c|c|c|c|}
\hline \multirow{2}{*}{ Fasting period (hours) } & \multirow{2}{*}{$\mathrm{n}$} & \multicolumn{2}{|c|}{ Slaughter Steps* } & \multirow[t]{2}{*}{$\mathrm{P}$ value ${ }^{* *}$} \\
\hline & & $\mathrm{A}$ & $\mathrm{B}$ & \\
\hline 2 to 24 & 30 & $3.00(\mathrm{v} 1.20)$ & $3.69( \pm 1.33)$ & 0.0007 \\
\hline 48 to 72 & 30 & $2.95( \pm 0.98)$ & $3.00( \pm 1.05)$ & 0.4067 \\
\hline $\mathrm{P}$ value $* * *$ & & 0,4390 & 0,0013 & \\
\hline
\end{tabular}

*A: after bleeding; B: after the carcass cleaning; ** Mann-Whitney test $(\mathrm{P}<0.05)$;*** Wilcoxon matched-pairs signed rank test $(\mathrm{P}<0.05)$.

Table 2. Mean counts (log CFU/ grams) of coliform at $35^{\circ} \mathrm{C}$ in bullfrog carcasses subjected to different fasting period, collected at two steps of the slaughtering process, in a slaughterhouse located in the state of Minas Gerais-Brazil

\begin{tabular}{|c|c|c|c|c|}
\hline \multirow{2}{*}{ Fasting period (hours) } & \multirow{2}{*}{$\mathrm{n}$} & \multicolumn{2}{|c|}{ Slaughter Steps* } & \multirow[t]{2}{*}{$\mathrm{P}$ value** } \\
\hline & & $\mathrm{A}$ & B & \\
\hline 2 to 24 & 30 & $0.98( \pm 0.94)$ & $0.79( \pm 0.62)$ & 0.6808 \\
\hline 48 to 72 & 30 & $0.84( \pm 0.79)$ & $0.69( \pm 0.63)$ & 0.4973 \\
\hline $\mathrm{P}$ value $* *$ & & 0.6100 & 0.4118 & \\
\hline
\end{tabular}

*A: after bleeding; B: after the carcass cleaning; ** Mann-Whitney test $(\mathrm{P}<0.05)$;** Wilcoxon matched-pairs signed rank test $(\mathrm{P}<0.05)$.

Table 3. Mean counts (log CFU/ grams) of Escherichia coli in bullfrog carcasses subjected to different fasting period, collected at two steps of the slaughtering process, in a slaughterhouse located in the state of Minas Gerais-Brazil

\begin{tabular}{lcccc}
\hline \multirow{2}{*}{ Fasting period (hours) } & \multirow{2}{*}{ Slaughter Steps* } & P value** \\
\cline { 3 - 5 } & 30 & $\mathrm{~A}$ & $\mathrm{~B}$ & \\
\hline 2 to 24 & 30 & $0.08( \pm 0.54)$ & $0.03( \pm 0.28)$ & 0.4352 \\
48 to 72 & & 0.4685 & $0.11( \pm 0.47)$ & 0.7615 \\
P value*** & & 0.722 & \\
\hline
\end{tabular}

*A: after bleeding; B: after the carcass cleaning; ** Mann-Whitney test $(\mathrm{P}<0.05)$;*** Wilcoxon matched-pairs signed rank test $(\mathrm{P}<0.05)$.

Table 4. Occurrence of Escherichia coli and Salmonella spp. in bullfrog carcasses subjected to different fasting period, collected at two steps of the slaughtering process, in a slaughterhouse located in the state of Minas Gerais-Brazil

\begin{tabular}{|c|c|c|c|c|c|c|}
\hline \multirow{3}{*}{ Fasting period (hours) } & \multirow{3}{*}{$\mathrm{n}$} & \multicolumn{2}{|c|}{ Slaughter Steps* } & & & \multirow{3}{*}{$\mathrm{P}$ value** } \\
\hline & & \multicolumn{2}{|c|}{$\mathrm{A}$} & \multicolumn{2}{|c|}{ B } & \\
\hline & & Positive & $\%$ & Positive & $\%$ & \\
\hline \multicolumn{7}{|l|}{ Escherichia coli } \\
\hline 2 to 24 & 30 & 21 & 70.0 & 15 & 50.0 & 0.1872 \\
\hline 48 to 72 & 30 & 13 & 43.3 & 6 & 20.0 & 0.0946 \\
\hline $\mathrm{P}$ value** & & \multicolumn{2}{|c|}{0.0673} & \multicolumn{2}{|c|}{0.0292} & \\
\hline \multicolumn{7}{|l|}{ Salmonella spp. } \\
\hline 2 to 24 & 70 & 7 & 10.0 & 9 & 12.9 & 0.7914 \\
\hline 48 to 72 & 70 & 2 & 2.9 & 1 & 1.4 & 1.0000 \\
\hline $\mathrm{P}$ value** & \multicolumn{3}{|c|}{0.4828} & \multicolumn{2}{|c|}{0.0173} & \\
\hline
\end{tabular}

*A: after bleeding; B: after the carcass cleaning; **Fisher's exact test $(\mathrm{P}<0.05)$

Regarding the occurrence of Salmonella spp. in 140 carcasses, there was no difference between the two slaughter points analyzed, with $6.43 \%$ (9/140) of positive samples being identified at point A and $7.14 \%(10 / 140)$ at point B. Again, there was a positive influence from the longer fasting period, and an $11.5 \%$ drop in the occurrence of Salmonella spp. was observed in the 
carcasses evaluated at step B (Table 4). Among the 19 isolates of Salmonella spp. found, 3 were classified as $S$. Infantis (16\%) and 16 as $S$. Newport (84\%).

\section{DISCUSSION}

In Brazil, although amphibians are mentioned in the Regulation of the Industrial and Sanitary Inspection of Products of Animal Origin, there is still no specific legislation on the stages of their slaughter and processing, such as the ideal period of pre-slaughter fasting (Brasil, 2017). Usually, the period of 24 to 48 hours of pre-slaughter fasting is used for the slaughter of bullfrogs as an extrapolation of the rules applicable to other species, without considering, however, particularities of the digestive system of amphibians, type of feeding, and the impacts of these variations on the microbiological quality of the final product (Cribb et al., 2013).

For animals such as cattle and pigs, for example, there is a definition of a maximum fasting period of up to 24 hours (Brasil, 2000). For other species, however, this maximum fasting period of 24 hours may not be sufficient. Bermejo-Poza et al. (2017) evaluated the influence of different times of preslaughter fasting in trout and found that complete intestinal emptying occurs after 4 days of fasting (96 hours). In the case of bullfrogs, the present study indicated that a fasting period of 48 to 72 hours brings benefits to the microbiological quality of the carcass when compared to fasting periods up to 24 hours. As most aquatic animals, amphibians are ectotherms, and the environmental temperature interferes on metabolism and consequently the intestinal emptying. In our study, the average temperature was $24.83 \pm 1.35^{\circ} \mathrm{C}$, providing adequate condition for bullfrog growth and consequently the function of digestive tract, according to Clayton, 2005 and Cribb et al., 2013.

For aerobic mesophilic bacteria, a short fasting period ( 2 to 24 hours) resulted in carcasses with higher count values in step B of the slaughter process, probably as a result of the short time that they remained in the fasting pen, with clean environment and water. Considering that these animals are raised in flooded pens, there is an inevitable cross contamination that highlights the importance of good practices in rearing and in the procedures that precede the slaughter process
(Cribb et al., 2013; Ogoanah et al., 2017). On the other hand, the individual assessment of this relationship between fasting and AM count may not be the only explanation for the results found. This hygiene indicator microorganism is related to general conditions of the environment and, therefore, may also be influenced by other variables such as the hygiene of the industry, employees, and the quality of the slaughter process carried out at the time of the analysis (Garayoa et al., 2016).

In addition, in Brazilian legislation, there are no established limits for counting AM in bullfrog meat, however, as a basis of comparison the allowed value for poultry meat is $6.7 \mathrm{log} / \mathrm{g}$ $\left(5 \times 10^{6}\right)$, for cattle and pork is 6log / g $\left(10^{6}\right)$ and for fish is $3 \log / \mathrm{g}\left(10^{3}\right)$. Thus, using the values defined for fish, it is observed that the average count found after the final cleaning was at the limit for the carcasses subjected to a longer fasting period (3logCFU / g) and above the limit for those subjected to short fasting periods (3.69logCFU / g) (Brazil, 2019).

The lack of influence of fasting on the TCC and EC values may be related to the low counts (Table 2 and 3) observed for these microorganisms in the present study. These good results can be attributed to the quality of the slaughter process, origin of the animals, or characteristics inherent to the processing system, which individually or with a summation effect did not allow to observe great variations in the counts of these hygiene indicators (Cribb et al., 2013; Walke et al., 2014). For other species, this impact has already been demonstrated, with varying intensities according to the studied species (Pointon et al., 2012; Pereira et al., 2013).

For CTT there are no limits foreseen in the legislation, however, for $E$. coli the limits for poultry meat are $3.7 \mathrm{log} / \mathrm{g}\left(5 \times 10^{3}\right)$, for bovine and swine is $2 \log / \mathrm{g}\left(10^{2}\right)$ and for fish is $2.7 \log / \mathrm{g}$ $\left(5 \times 10^{2}\right)$. For this microorganism it can be noted that the contamination of the bullfrog meat was much lower in both analyzed fasting periods (Brazil, 2019). Regarding the impact of fasting on the presence of Escherichia coli and Salmonella spp, it was possible to show that the period between 48 and 72 hours was sufficient to reduce the occurrence of these microorganisms. This result is important due to the fact that $E$. coli is one of the main indicators of fecal contamination. In 
addition, this genus of bacteria can be potentially pathogenic for consumers (Aijuka and Buys, 2019). Gray et al. (2007), in an experiment with bullfrogs, inoculated the tadpoles orally with Escherichia coli O157: H7, and after 14 days, more than half of the animals were positive for the pathogen, suggesting that bullfrogs are suitable hosts for E. coli O157: H7.

For Salmonella, the current legislation in Brazil defines that the limit for this pathogen is the absence of 25 grams for all meats (poultry, cattle, pork and fish). Therefore, it is noted that for this microorganism $7.14 \%$ (10/140) carcasses from this study would be in disagreement with the legislation (Brazil, 2019). Salmonella spp., along with $E$. coli, is one of the main bacterial genera associated with foodborne disease outbreaks and, therefore, the responsibility to reduce the contamination by these bacteria should be shared by the entire animal product chain (Doenças..., 2019; Center..., 2020). In the case of amphibians, it is known that they can be asymptomatic carriers of Salmonella spp., and the longer fasting time tested in the present study (48 to 72 hours) contributed to greater intestinal emptying and less recovery of this bacterium during the slaughter process (Schettino et al., 2006; Ribas and Poonlaphdecha, 2016; Dadié et al., 2017).

Furthermore, it was observed that the isolates found in the present study belong to serotypes relevant to the public health area ( $S$. Newport and Salmonella Infantis) (Al-Rifai et al., 2020). Salmonellla Newport is one of the foodborne serotypes most associated with diseases in humans. In a study conducted in the United States, between 1998 and 2015 this serotype was among the five most frequently associated with outbreaks, being responsible for $11.7 \%$ of them, with an incidence of 1.27 per 100,000 inhabitants (Luvsansharav et al., 2020). In the same way, Salmonella Infantis is also cited among the 20 serotypes most associated with diseases in humans, however, less frequently linked to outbreaks (Monte et al., 2019; Luvsansharav et al., 2020). In addition, multidrug-resistant Salmonella are increasingly being identified, making treatment of patients increasingly difficult (Monte et al., 2019). Although not the focus of the present study, further studies will be important to characterize these isolates and understand the real risk to consumers' health.
Despite not being evaluated in the present study, the impact of long periods of fasting on slaughter logistics, carcass weight, and well-being may reveal disadvantages of this fasting option, which would justify further studies within the studied fasting range (greater than 24 hours and up to 72 hours) to identify possible variations. Also, the impact of different fasting periods on the count of other microorganisms, such as coagulase-positive staphylococci, may also be the focus of future studies.

\section{CONCLUSION}

Among the evaluated fasting ranges, it was possible to conclude that the period of 48 to 72 hours of pre-slaughter fasting has benefits for the microbiological quality of bullfrog carcasses, including the reduction of aerobic mesophilic bacteria and the presence of Escherichia coli and Salmonella spp.

\section{ACKNOWLEDGEMENTS}

The support of Fundação de Amparo à Pesquisa do Estado de Minas Gerais (FAPEMIG), Coordenação de Aperfeiçoamento de Pessoal de Nível Superior (CAPES), Conselho Nacional de Desenvolvimento Científico e Tecnológico (CNPQ), and Programa de Educação Tutorial (PET).

\section{REFERENCES}

AIJUKA, M.; BUYS. E.M. Persistence of foodborne diarrheagenic Escherichia coli in the agricultural and food production environment: Implications for food safety and public health. Food Microbiol., v.82, p.363-370, 2019.

ALMEIDA, M.V.; SILVA JR, A.; NERO, L.A. Evaluation of targer sequences for the polymerase chain reaction-based detection of Salmonella in artificially contaminated beef. Foodborne Pathog. Dis, v.11, p.111-118, 2014.

AL-RIFAI, R.H.; CHAABNA, K.; DENAGAMAGE, T.; ALALI, W.Q. Prevalence of non-typhoidal Salmonella enterica in food products in the Middle East and North Africa: a systematic review and meta-analysis. Food Control., v.109, p.1-21, 2020.

ALVAREZ, J.; SOTA, M.; VIVANCO, A.B. et al. Development of a multiplex PCR technique for 
detection and epidemiological typing of Salmonella in human clinical samples. J. Clin. Microbiol., v.42, p.1734-1738, 2004.

BERMEJO-POZA, R.; FUENTE, J.D.L.; PÉREZ, C. et al. Determination of optimal degree days of fasting before slaughter in rainbow trout (Oncorhynchus mykiss). Aquaculture, v.473, p.272-277, 2017.

BRASIL. Ministério da Agricultura Pecuária e Abastecimento. Instrução Normativa $\mathrm{n}^{\circ} 03$ de 17 de janeiro de 2000. Regulamento técnico de métodos de insensibilização para o abate humanitário de animais de açougue. Diário Oficial da União, Brasília, 24 jan. 2000.

BRASIL. Ministério da Agricultura Pecuária e Abastecimento. Decreto ${ }^{\circ} 9.013$ de 29 de março de 2017. Regulamento da Inspeção Industrial e Sanitária de Produtos de Origem Animal RIISPOA. Diário Oficial da União, Brasília, 30 mar. 2017.

BRASIL. Ministério da Saúde. Instrução Normativa $\mathrm{n}^{\circ} 60$ de 23 de dezembro de 2019. Estabelece as listas de padrões microbiológicos para alimentos prontos para oferta ao consumidor. Diário Oficial da União, Brasília, 26 dez. 2019.

CANTLAY, J.C.; INGRAM, D.J.; MEREDITH, A.L. A Review of zoonotic infection risks associated with the wild meat trade in Malaysia. Ecohealth, v.14, p.361-388, 2017.

CASON, J.A.; BERRANG, M.E.; SMITH, D.P. Recovery of bacteria from broiler carcasses rinsed zero and twenty-four hours after immersion chilling. Poult. Sci., v.85, p.333-336, 2006.

CENTER for Disease Control and Prevention. Reports of selected Salmonella outbreak investigations, 2020. Available in: https://www.cdc.gov/salmonella/outb reaks.html. Accessed em: 09 mar. 2020.

CLAYTON, L.A. Amphibian gastroenterology. Vet. Clin. Exot. Anim., v.8, p.227-245, 2005.

CRIBB, A.Y.; AFONSO, A.M.; MOSTÉRIO, C.M.F. Manual técnico de ranicultura. Brasília, DF: Embrapa, 2013. 76p.
DADIÉ, A.; BLÉ, Y.C.; KOUADIO-NGBESSO, N.; FANTODJI, A.; DJÈ, K.M. Prevalence, serotype and presence of invasion gene in Salmonella isolated from frog meat obtained from western region of Côte d'Ivoire. Int. J. Appl. Microbiol. Biotechnol. Res., v.5, p.75-81, 2017.

DOENÇAS transmitidas por alimentos: causas, sintomas, tratamentos e prevenção. Brasília: Ministério da Saúde. 2019. Disponível em: https://saude.gov.br/saude-de-a-z/doencastransmitidas-por-alimentos. Acessado em: 28 abr. 2020.

GARAYOA, R.; YÁNEZ, N.; DÍEZ-LETURIA, M.; BES-RASTROLLO, M.; VITAS, A.I. Evaluation of prerequisite programs implementation and hygiene practices at social food services through audits and microbiological surveillance. J. Food Sci., v.81, p.M921-M927, 2016.

GRAY, M.J.; RAJEEV, S.; MILLER, D.L. et al. Preliminary evidence that American Bullfrogs (Rana catesbeiana) are suitable hosts for Escherichia coli O157:H7. Appl. Environ. Microbiol., v.73, p.4066-4068, 2007.

INTERNATIONAL Organization for Standardization. ISO 6579:2002. Microbiology of food and animal feeding stuffs - Horizontal method for the detection of Salmonella spp. 2002.

LI, X.; RAHIMNEJAD, S.; WANG, L. et al. Substituting fish meal with housefly (Musca domestica) maggot meal in diets for bullfrog Rana (Lithobates) catesbeiana: Effects on growth, digestive enzymes activity, antioxidant capacity and gut health. Aquaculture, v.499, p.295-305, 2019.

LIN, J.; ZENG, Q., ZHANG, C. et al. Effects of Bacillus subtilis supplementation in soybean meal-based diets on growth performance, diet digestibility and gut health in bullfrog Lithobates catesbeianus. Aquacult. Rep., v.16, p.1-8, 2020.

LUVSANSHARAV, U.O; VIEIRA, A.; BENNETT, S. et al. Salmonella serotypes: A novel measure of association with foodborne transmission. Foodborne Pathog. Dis., v.17, p.151-155, 2020. 
MONTE, D.F.; LINCOPAN, N.; BERMAN, H. et al. Genomic features of high-priority Salmonella enterica serovars circulating in the food production chain, Brazil, 2000-2016. Sci. Rep., v.9, p.1-12, 2019.

OGOANHA, O.S.; OKAFOR, A.E.; EYONG, M.M. Effect of different preparatory methods on microbial load of the edible frog Hoplobatrachus occipitalis from Aguleri, Anambra State, Nigeria. Niseb J., v.17, p.91-95, 2017.

OLIVEIRA, L.P.L.; SEIXAS FILHO, J.T.; PEREIRA, M.M.; MELLO, S.C.R.P. Frog meat in special diets: potential for use as a functional food. Bol. Inst. Pesca, v.44, p.44-106, 2017.

PAHOR-FILHO, E.; MANSANO, C.F.M.; PEREIRA, M.M.; DE STÉFANI, M.V. The most frequently bullfrog productive systems used in Brazilian aquaculture: a review. Aquacult. Eng., v.87, p.1-10, 2019.

PEREIRA， R.E.P.; MARTINS, M.R.F.B.; MENDES, A.A. et al. Effects of pre-slaughter fasting on broiler welfare, meat quality, and intestinal integrity. Braz. J. Poult. Sci., v.15, p.119-122, 2013.
POITON, A. KIERMEIER, FEGAN, N. Review of the impact of pre-slaughter feed curfews of cattle, sheep and goats on food safety and carcass hygiene in Australia. Food Control, v.26, p.313321, 2012.

RIBAS, A.; POONLAPHDECHA, S. WildCaught and farm-reared amphibians are important reservoirs of Salmonella, a study in North-East Thailand. Zoonoses Public. Health, v.64, p.106110, 2016.

SCHETTINO, D.N.; CANÇADO, S.V.; BAIÃO, N.C. et al. Efeito do período de jejum pré-abate sobre o rendimento de carcaça de frango de corte. Arq. Bras. Med. Vet. Zootec., v.58, p.918-924, 2006.

WALKE, J.B.; BECKER, M.H.; LOFTUS, S.C. et al. Amphibian skin may select for rare environmental microbes. ISME J., v.8, p.22072217, 2014. 